\title{
Importance of dietary amino acids in the nutrition of grazing ruminants
}

\author{
WC Ellis 1, TH Hill 2, \\ 1Texas A \& M University, College Station TX $77845 ; 2$ The University of Maine, Orono, ME 04469, USA
}

The value of proteins from corn $(Z)$, menhaden fishmeal (M), blood meal (B), cotton seed meal (C) or feather meal $(F)$ as supplements for heifers grazing either bermudagrass (Cynodon dactylon) or annual ryegrass (Lolium multiflorum) was evaluated. Flow of digesta and protein fractions was estimated by constant infusion of two rare earth acetates and $\mathrm{Na}_{2}{ }^{35} \mathrm{SO}_{4}$ into the rumen and analysis of duodenal and rectal digesta. The experimental design for the bermudagrass experiment involved supplements of $Z,(8 \%$ crude protein, $\mathrm{CP}$ ) or $34 \% \mathrm{CP}$ supplements formulated with $Z$ plus $M, F$ and $C$ fed twice daily in a 2 period replicated design. Heifers grazing ryegrass pastures received supplements $Z, M, F, C$, blood meal (B), a cottonseed meal-urea block $(P)$ or a mineral control in a 7 by 3 Youden square. Digesta entities determined included true protein (TP, trichloroacetic insoluble, Lowry reactive), microbial protein (MP) and UIP as TP-MP. The fractional UIP of forage origin was computed from animals fed mineral control and used to resolve UIP for forage and supplement. The chemical score (CS) of the supplementary proteins (CSSP) and forage UIP were computed from their intake and amino acid composition assuming no differential ruminal degradation of amino acids. The CS of digestible intestinal TP (STP, CSSTP) was calculated as the expected amino acid composition of the mixture of proteins involving UIP from the supplement and the forage and from MP. The flux of net protein was calculated as STP * CSSTP. There was no significant $(P>0.8)$ relationship between $\mathrm{OMI}$ and quantities of TP (UIP or STP). In contrast, relations involving amino acid composition,i.e. CS, were generally significant, especially for the ryegrass experiment (table). It is concluded that the profile of absorbed amino acids is important in nutrition of the grazing ruminant and appears to modulate forage intake.

Table. Relations between daily voluntary intake of grazed forage (OMI) and flux of estimated variables. CSSP $=$ chemical score of supplemental protein, CSSTP $=$ chemical score of estimated total intestinal protein (STP), NPF = flux of net protein estimated from CSSTP, NPF/DE = NPF/intestinal flux of metabolizable energy.

\begin{tabular}{lllc} 
Forage & $\begin{array}{l}\text { Dependent } \\
\text { Variable }\end{array}$ & $\begin{array}{l}\text { Regression equation ; daily OMI, } \\
\text { g/kg of body weight }=\end{array}$ & Prob. \\
Bermuda & CSSP & $=13.27+0.100^{*} \mathrm{CSSP}$ & 0.02 \\
Bermuda & $\mathrm{CSSTP}$ & $=11.09+0.113^{*} \mathrm{CSSTP}$ & 0.11 \\
Bermuda & $\mathrm{NPF}$ & $=11.21+5.96^{*} \mathrm{~g} \mathrm{NPF} / \mathrm{kg} \mathrm{BW}$ & 0.20 \\
Bermuda & $\mathrm{NPF} / \mathrm{ME}$ & $=24.37-24.37^{*} \mathrm{~g} \mathrm{NPF} / \mathrm{kcal} \mathrm{ME}$ & 0.32 \\
Ryegrass & $\mathrm{CSSP}$ & $=14.14+0.217^{*} \mathrm{CSSP}$ & 0.008 \\
Ryegrass & $\mathrm{CSSTP}$ & $=-15.91+0.607^{*} \mathrm{CSSTP}$ & 0.052 \\
Ryegrass & $\mathrm{NPF}$ & $=8.25+13.27^{*} \mathrm{~g} \mathrm{NPF} / \mathrm{kg} \mathrm{BW}$ & 0.03 \\
Ryegrass & $\mathrm{NPF} / \mathrm{ME}$ & $=45.90-24.05^{*} \mathrm{~g} \mathrm{NPF} / \mathrm{kcal} \mathrm{ME}$ & 0.03 \\
\hline
\end{tabular}

